\title{
The Study on the Relationship between the Environmental and Financial Performances of Corporates Which Have Adopting the System of Environmental Accounting in Taiwan
}

\author{
Wei-Lun Huang ${ }^{1}$, Yan-Kai $\mathrm{Fu}^{2}$,* \\ ${ }^{1}$ School of Finance, Wenzhou Business College, China \\ ${ }^{2}$ Department of Aviation Services and Management, China University of Science and Technology \\ *Corresponding author
}

\begin{abstract}
The purpose of this paper is to study the relationship between the environmental and financial performance of Corporates. For the environmental awareness of people, the social responsibility of companies and the environmental policies and laws of government, more and more companies would adopt the system of environmental accounting, and then they would disclosure their environmental performances. From the review of literature and the statistics results on the financial and environmental performances of listed companies which had adopted the environmental accounting system in Taiwan, the results are: 1.the adopting on the system of environmental accounting might make the corporations' financial performances worse, but not significantly make corporations' environmental performances better. 2. There should be a positive relationship between the environmental performance and financial performance of companies.
\end{abstract}

\section{Introduction}

Due to the raise of governments' and enterprises' environmental performance selfrequirements under the promotion of people's environmental awareness and the requirements of environmental agreements, such as the reduction requirement of greenhouse gas emissions for the Kyoto Protocol, in addition to pursuing their financial performance, enterprises also need to incorporate environmental performance (as the environmental protection concepts of products, the environmental impact of wastes, the social responsibility) into their objectives and decision-making process of business strategies. For the progress of science, technology and social economics, the unit price and types of environmental costs that companies need to bear have increased, while traditional accounting methods could not show environmental expenditures and benefits, so more and

* Corresponding author: yankaifu@cc.cust.edu.tw 
more countries and enterprises have used the system of environmental accounting. ([4], [10-12])

This paper would analyze the relationship between the environmental and financial performances of corporates which have adopting the system of environmental accounting. There were different opinions about the correlations between environmental performance and financial performance of corporates in the past literatures. As the unified agreement which the reduction of pollution could really improve the profitability of enterprises has not been reached.

Financial accounting and managerial accounting, traditional types of accounting, lacks systematical measurement of environmental activities (as environmental accidents, the consumption of natural resource and so on), which leads to concealment or repeat accounting on the environmental protection expenditures or environmental benefits of corporates. Enterprises cannot make correct or exact decisions of management due to insufficient effective information of their environmental performances. Thus, the system of environmental accounting has been used by many enterprises. The International Federation of Accountants (1998) defines environmental accounting as "Environmental Management Accounting (EMA)", and EMA is the management of the environmental performance and economic performance through the development and implementation of appropriate environmental accounting system which involves with the lifecycle cost, the accounting and estimation of total cost and benefit, and strategic planning. ([6])

In this paper, the system of environmental accounting is designed to help the enterprise improve its environmental performance by recording its direct and indirect costs and benefits for environment-related activities, then achieve the objective of sustainable operation for the enterprise. In the other side, the system of environmental accounting is capable of measuring and disclosing environmental data and activity costs of the enterprise, and then it could provide external users with relevant environmental information of the enterprise itself and the enterprise's involvement in environmental protection activities. The United Nations Division for Sustainable Development (UN-DSD) (2001) thought EMA could help the enterprise achieve its sustainable development goal by analyzing, using and linking the financial and non-financial information combined with the company policies. EMA is also a decision-support tool which could provide the company with timely and forward-looking information on the cost for the design, production, and sale of product and the investment strategies.

The scope of environmental accounting system could be divided into macro and micro levels, and its users could consist of external users and internal users. (See Table 1) And this study is focus on the micro level of the environmental accounting system that is the environmental accounting system of the enterprise. In short, the macro level of environmental accounting system is the measurement on the national consumption of natural resource, green GDP and etc.; its micro level is concerned with the enterprise financial accounting issues pertaining to the environment, as the identification and accounting of environmental cost, and the assist during their decision-making such as cost sharing, capital budgeting and product pricing. Hua, et al. ([10]) found the disclosure characteristics and influencing factors of environmental accounting information are the main focus of the related literature in China. (EPA, 2005)

Table 1. The macro and micro level of environmental accounting system.

\begin{tabular}{|l|c|l|c|}
\hline \multicolumn{2}{|c|}{ Classification } & \multicolumn{1}{c|}{ Definition } & User \\
\hline $\begin{array}{l}\text { Macro } \\
\text { Level }\end{array}$ & Green GDP & $\begin{array}{l}\text { The environmental indicators of the macro- } \\
\text { economy with its focus that is the national } \\
\text { consumption of natural resource over a certain } \\
\text { period by the entity or currency unit. }\end{array}$ & External user \\
\hline Micro & Financial & The Estimation and disclosure of environmental & Investors, \\
\hline
\end{tabular}




\begin{tabular}{|c|c|l|c|}
\hline Level & accounting & cost and environmental debt. & $\begin{array}{c}\text { creditors and } \\
\text { other outsiders }\end{array}$ \\
\cline { 2 - 5 } & $\begin{array}{l}\text { Managerial } \\
\text { accounting }\end{array}$ & $\begin{array}{l}\text { The Confirmation and calculation of } \\
\text { environmental cost which is helpful for the } \\
\text { enterprise to make decisions about cost sharing, } \\
\text { capital budgeting, product design, pricing and } \\
\text { so on. }\end{array}$ & $\begin{array}{c}\text { Internal } \\
\text { managerial } \\
\text { staff }\end{array}$ \\
\cline { 2 - 5 } & $\begin{array}{c}\text { Auditing or } \\
\text { confirmation } \\
\text { identification }\end{array}$ & $\begin{array}{l}\text { The Auditing or confirmation service for } \\
\text { financial or environmental information of the } \\
\text { enterprise. }\end{array}$ & $\begin{array}{c}\text { Investors, } \\
\text { creditors and } \\
\text { other outsiders }\end{array}$ \\
\hline
\end{tabular}

Environmental accounting system could apply to financial accounting, managerial accounting and cost accounting with the annual disclosure of the operation results, cost sharing and control, managerial decision-making, which is shown in Fig 1. The items of environmental accounting system should base on the environmental cost and benefit of the enterprise during its operation. However, in a broad sense, its scope should expand to the working environment of the employees, so the environmental accounting system could be applied to the information disclosure, decision-making and evaluation for enterprise sustainable operation, the analysis of product cost, productivity and competitiveness. Liu and $\mathrm{Lu}$ ([9]) suggested promoting the environmental accounting system for environmental improvement, resource utilization rate and sustainable development, etc. Liu and $\mathrm{Lu}$ ([9]) suggested promoting the environmental accounting system for environmental improvement, resource utilization rate and sustainable development, etc.

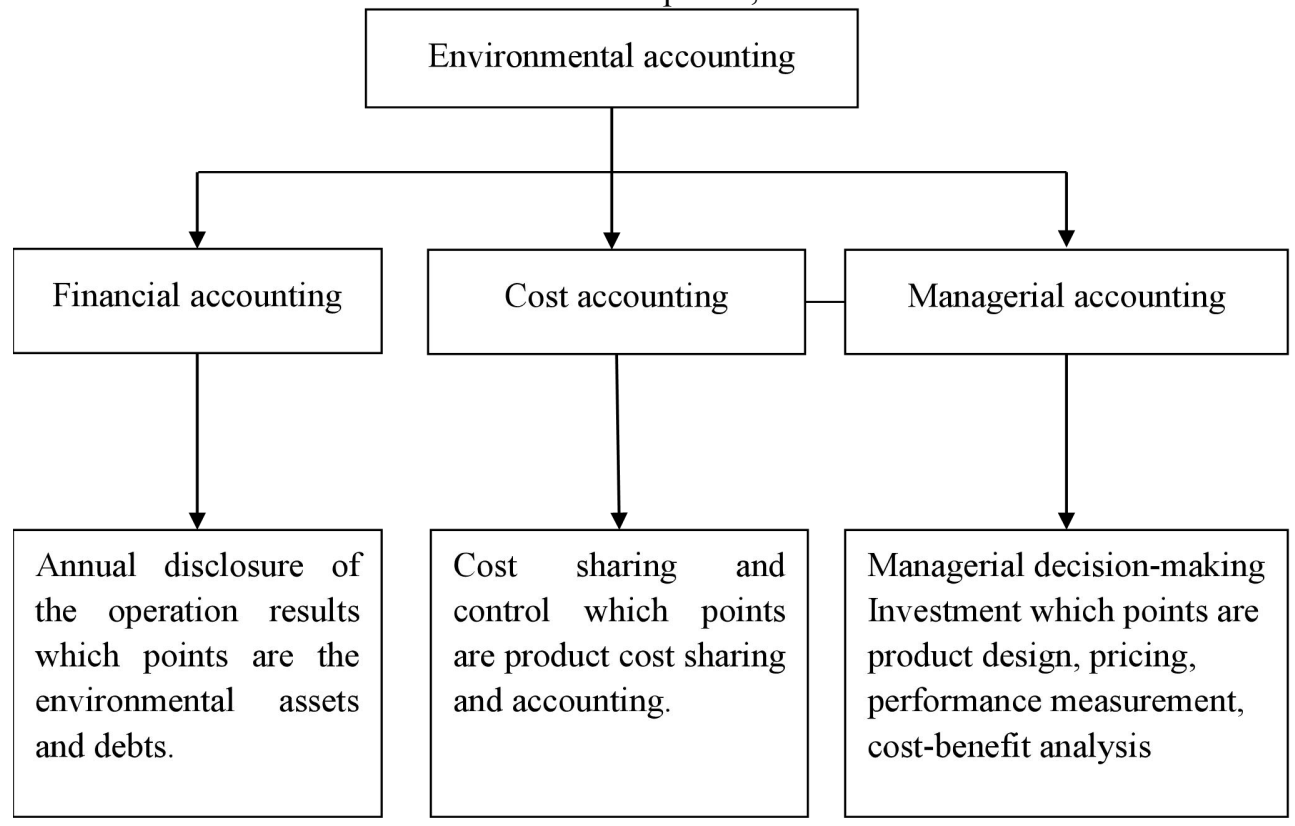

Fig. 1. The scope of the enterprise's environmental accounting system.

In addition to the introduction, the structure of paper is divided into three parts, the second part is empirical analysis, and the third part is the conclusion and suggestion.

\section{Empirical analysis}


Many papers have studied the impact on the corporations' financial performance and environmental performance by the system of environmental accounting, as Burnett and Hansen ([12]) thought the environmental management accounting applications are the microfundation of Green GDP, and they could be used to certify the reality and relationship of the corporations' financial performance. Schaltegger and Zvezdov ([13]) had explored the relationship between material flow cost accounting and environmental management accounting.

The purpose of this study is to explore the relationship between environmental performance and financial performance of the enterprise. From the review of literatures, this paper set the variables of enterprise's financial performance as the environmental fines, the return rate on stockholder's equity and assets, and net profit ratio, and the variables of enterprise's environmental performance as the quantities of air pollution, wastewater, waste, and waste recycling, and the disposal cost of waste. In this study, environmental fine will be adopted as an indicator of financial performance rather than environmental performance. As Al-Tuwaijri, et al. ([1]) found the good environmental performance of the Enterprise is clearly associated with its good economic performance. Bragdon, and Marlin ([3]) argued that pollution reduction would help increase profitability of paper companies.

According to the literature review, this paper defines the variable and its calculation methods as follows: 1. Environmental fine is the company's money loss (fine) due to environmental pollution; 2. The return rate on equity $(\%)=$ (net profit after tax $/$ stockholder's equity) $\times 100 ; 3$. The return rate on assets $(\%)=\{[$ net profit after tax + interest $\times(1$-tax rate $)] /$ total assets $\} \times 100 ; 4$. Net profit ratio $(\%)=($ net profit after tax $/$ net sales) $x 100 ; 5$. The quantities of air pollution are the emissions of greenhouse gas and air pollutants such as nitrogen oxides; 6 . The quantities of wastewater are wastewater discharge amount reported in the Corporate Sustainability Report or Corporate Social Responsibility Report. 7. The quantities of waste are waste generation amount in the Corporate Sustainability Report or Corporate Social Responsibility Report. 8. The quantities of waste recycling are waste recycling amount indicated in the Corporate Sustainability Report or Corporate Social Responsibility Report. Waste burial and incineration are not included. 9. The disposal costs of waste are waste disposal costs listed in the Corporate Sustainability Report or Corporate Social Responsibility Report. As Donovan ([8]) have extended the applicability and predictive power of legitimacy theory by investigating to environmental disclosures in the annual report of three large Australian public companies.

All data in this study were taken from the three years before the implementation of environmental accounting system by each company up to 2014, and companies that have implemented environmental accounting in the public offering or listing in the market are selected as samples in this study. After eliminating public enterprises, unlisted companies and companies with insufficient data, 32 valid samples remained. The data of variables are from the financial ratio analysis on the market observation website of Taiwan Stock Exchange, the annual financial report of each company, the official website of each company, the environmental expenditure in the annual report of the shareholders' meetings in each company and the company's published Corporate Sustainability Reports (CSR) or Corporate Social Responsibility Reports (CSR Reports).

In Table 2, it is shown that the narrative statistics of each variable. In terms of the financial performance of the enterprise, the average environmental fine is TWD 520,892.8 with the standard deviation of $1,990,107.2$. The average return rate on stockholder's equity is $-16.4 \%$ with the standard deviation of $432.2 \%$. The average return rate on assets is $4.7 \%$ with the standard deviation of $7.2 \%$. The average net profit ratio is $7.1 \%$ with the standard deviation of $18.4 \%$. In terms of the environmental performance of the enterprise, the average quantities of air pollution are $392,412.8$ tons with the standard deviation of 
$14,803,843.7$. The average quantities of wastewater are $1,308,384.9$ tons with the standard deviation of $408,944.1$. The average quantities of waste are 10,208.4 tons with the standard deviation of $668,429.7$. The average quantities of waste recycling are $61,005.14$ tons with the standard deviation of $358,160.7$ tons. The average disposal cost of waste is TWD $22,534,173.1$ with the standard deviation of 127018440.7 .

Table 2. The narrative statistics of the variables.

\begin{tabular}{|c|c|c|c|c|}
\hline Variable & Min & Max & Average & $\begin{array}{c}\text { Standard } \\
\text { deviation }\end{array}$ \\
\hline $\begin{array}{c}\text { Environmental fine } \\
\text { (TWD) }\end{array}$ & 0.0 & $27,663,100.0$ & $520,892.8$ & $1,990,107.2$ \\
\hline $\begin{array}{c}\text { The return rate on } \\
\text { stockholder's equity(\%) }\end{array}$ & -8553.0 & 37.63 & -16.42 & 432.2 \\
\hline $\begin{array}{c}\text { The return rate on } \\
\text { assets(\%) }\end{array}$ & -30.2 & 26.0 & 4.7 & 7.2 \\
\hline Net profit ratio(\%) & -108.9 & 104.7 & 7.1 & 18.4 \\
\hline $\begin{array}{c}\text { The quantities of air } \\
\text { pollution (tons) }\end{array}$ & 0.0 & $84,840,000.0$ & $3,924,127.8$ & $14,803,843.7$ \\
\hline $\begin{array}{c}\text { The quantities of } \\
\text { wastewater(tons) }\end{array}$ & 0.0 & $32,740,500.0$ & $1,308,349.9$ & $4,089,440.1$ \\
\hline $\begin{array}{c}\text { The quantities of waste } \\
\text { (tons) }\end{array}$ & 0.0 & $6,402,000.0$ & $102,086.4$ & $668,429.7$ \\
\hline $\begin{array}{c}\text { The quantities of waste } \\
\text { recycling (tons) }\end{array}$ & 0.0 & $2,739,538.0$ & $61,005.1$ & $358,160.7$ \\
\hline $\begin{array}{c}\text { The disposal costs of } \\
\text { waste (TWD) }\end{array}$ & 0.0 & $1,319,000,000.0$ & $22,534,173.1$ & $127,018,440.7$ \\
\hline
\end{tabular}

The reverse elimination method belonging to the stepwise regression method is adopted in this study. The independent variables of regression analysis contain the quantities of air pollution, wastewater, waste, and waste recycling, and the disposal cost of waste. The dependent variables include the environmental fines, the return rate on stockholder's equity and assets, and net profit ratio will be analyzed one by one.

Table 3 is the regression coefficients of the variables of enterprise's environmental performance to its environmental fine. The variable of enterprise's quantities of waste recycling is not persuasive, so it is excluded. The F value of ANOVA is 17.3, which means that the model is persuasive. All the VIF are all less than 10, which indicates that the model is not collinear. According to the regression analysis, it is known that enterprise's quantities of wastewater would influence its environmental fines the most with its significantly positive effects. Moreover, enterprise's quantities of air pollution and disposal costs of waste have significantly positive influences on its environmental fines.

Table 3. The regression coefficients of the variables of enterprise's environmental performance to its environmental fine and return rate on stockholder's equity.

\begin{tabular}{|c|c|c|c|c|c|}
\hline & Mode & $\begin{array}{c}\text { Unstandardized } \\
\text { Coefficients }\end{array}$ & $\begin{array}{c}\text { Standardized } \\
\text { coefficient }\end{array}$ & $\mathbf{T}$ & Collinear \\
\cline { 3 - 6 } & (constant) & 202409.41 & & $2.01 *$ & VIF \\
\cline { 2 - 6 } & $\begin{array}{c}\text { The quantities of air } \\
\text { pollution }\end{array}$ & 0.03 & 0.21 & $3.97 * *$ & 1.27 \\
\cline { 2 - 6 } $\begin{array}{c}\text { Environmental } \\
\text { Fine }\end{array}$ & $\begin{array}{c}\text { The quantities of } \\
\text { wastewater }\end{array}$ & 0.14 & 0.28 & $5.42 * *$ & 1.23 \\
\cline { 2 - 7 } & $\begin{array}{c}\text { The quantities of } \\
\text { waste }\end{array}$ & -0.29 & -0.10 & -1.76 & 1.39 \\
\hline
\end{tabular}




\begin{tabular}{|c|c|c|c|c|c|}
\hline & $\begin{array}{c}\text { The disposal costs of } \\
\text { waste }\end{array}$ & 0.003 & 0.17 & $3.03 * *$ & 1.36 \\
\hline
\end{tabular}

$*$ Significance $<0.05 ; * *$ Significance $<0.01$

For the regression of the variables of enterprise's environmental performance to its return rate on stockholder's equity, the variable of enterprise's environmental performance are not persuasive, so they are all excluded, so enterprise's environmental performance would not significantly affect its return rate on stockholder's equity.

Table 4 is the regression coefficients of the variables of enterprise's environmental performance to its return rate on assets and net profit ratio. The variables of enterprise's quantities of waste recycling and waste disposal cost are not persuasive, so they are excluded. The F values of ANOVA are 13.5 and 5.7, which means that the model is persuasive. All the VIF are all less than 10, which indicates that the model is not collinear. According to the regression analysis, it is known that enterprise's quantities of wastewater influence its return rate on assets and net profit ratio the most with its significantly negative effects. Moreover, enterprise's quantities of waste have a significantly positive influence on the return rate on assets. Last but not the least, enterprise's quantities of air pollution have a significantly negative impact on the return rate on assets and net profit ratio.

Table 4. Regression coefficients of the variables of enterprise's environmental performance to its environmental fine and return rate on stockholder's equity.

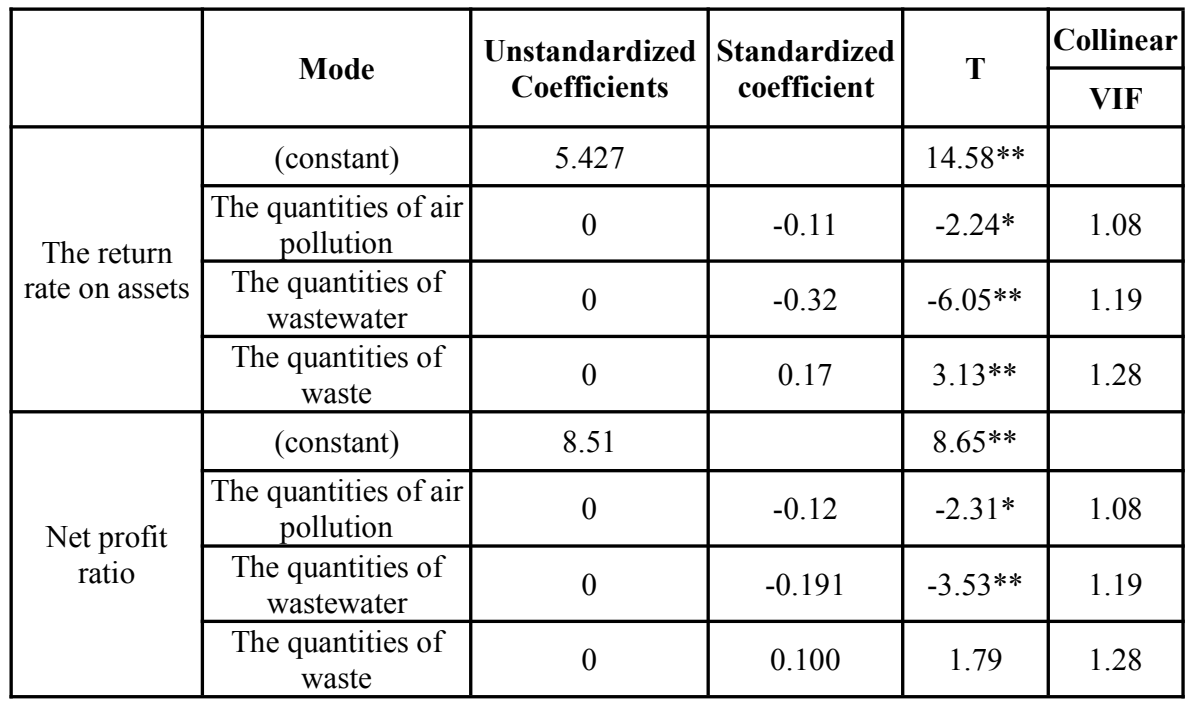

* Significance $<0.05$; ** Significance $<0.01$

\section{Conclusion and suggestion}

With more and more environmental protection policies in various countries becoming more and more strict, enterprises should maximize their financial performance under a certain level of their environmental performance. Enterprises could disclosure their environmental performance, establish their own image and fulfill their social responsibilities by the implement of the environmental accounting system. The environmental protection department of government would adjust environmental protection policies by the environmental performance of enterprises to, such as the regulations on pollution punishment and investment encourage of environmental protection. Financial institutions 
could make enterprises' risk assessment based on their environmental performance, and then make investment and financing decisions. People will purchase products with reference to their corporate image and environmental performance.

From the results of this study, it is proven that there is a significant correlation between enterprise's environmental performance and its financial performance. In general, the pollution reduced by the enterprise will increase its profitability and decrease environmental fines. The results of this study show that enterprise's quantities of wastewater is the most impact factor on its environmental fine, return rate on assets and net profit ratio, with its significantly positive effects on environmental fine, but its significantly negative effects on return rate on assets and net profit ratio. Besides, enterprise's quantities of air pollution also have a significantly positive impact on the environmental fine, but have a significantly negative impact on return rate on assets and net profit ratio. In turn, enterprise's quantities of waste have a significantly negative impact on the environmental fine, but have a significantly positive impact on return rate on assets and net profit ratio. And enterprise's waste disposal cost has significantly positive impacts on environmental fines.

Based on the research result, the following suggestions are made to the government, the enterprise and follow-up researchers:

1. The implementation of environmental accounting system cannot improve the profitability of enterprises, and the system of environmental accounting could promote the environmental function of the resource management and responsibility system by government, the guarantee system by law, and the public participation system by society, etc. The government could promote the implementation of the environmental accounting system by policies (as the economic incentives or tax reductions), environmental public interest action of the environmental law and so on to. ([6-7])

2. The enterprise with better environmental performance have better financial performance, so they should investment more on green procurement, green marketing and green processing as well as other environmental activities to cope with the strict environmental regulations and meet the requirements of the public for corporate environmental responsibility.

3. In some studies, it is believed that there is no significant correlation between environmental performance and financial performance of the enterprise, inconsistent with the conclusion drawn in this study. The reason might be the selected environmental performance indicators and industries. Subsequent researchers could adopt different environmental performance indicators for specific industries.

\section{References}

1. Al-Tuwaijri, S. A., Christensen, T. E. and Hughes, K. E., Organizations and Society, 29(5-6), 447-471 (2004)

2. Bennett, M. and James, P., Management Accounting, 76(10), 20-23 (1998)

3. Bragdon, J. H., and Marlin, J. A. T., Risk Management, 19(4), 157-169 (1972)

4. United Nations, "Kyoto Protocol" (1997)

5. USEPA, "Environmental Accounting Case Studies: Green Accounting at AT\&T", EPA (1995)

6. Zhang, B. and Shen, Z., Journal of Nanjing Tech University (Social Science Edition) 17(03), 68-76 (2018) 
7. Zhang, C., Wu, Y., The Negative Externalities of the Disclosure of Environmental Accounting Information of Listed Companies and the Regulation of Economic Law, 41(03), 47-50 (2017)

8. Donovan, G. O., Auditing and Accountability Journal, 15(3), 344-371 (2002)

9. Liu, C. and Lu, J., Communication of Finance and Accounting, 4, 9-12+4 (2017)

10. Hua, X., Zhu J., and Dai Y., Dynamics of Frontiers of Environmental Accounting Information Disclosure - Bibliometric Analysis based on CNKI Database Since 2000, 1, 38-41+4 (2017)

11. Burritt, R. L., and Saka, C., Journal of Cleaner Production, 14( 14), 1262-1275 (2006)

12. Burnett, R. D., and Hansen, D. R., Accounting, Organizations and Society, 33(6), 551581 (2008)

13. Schaltegger, S., and Zvezdov, D., Journal of Cleaner Production, 108(12), 1333-1341 (2015) 